\title{
The development of Bojongsari Water Attractions (Owabong)
}

\section{Kebijakan pengembangan Objek Wisata Air Bojongsari (Owabong)}

\author{
Solahuddin Kusumanegara*, M. Soebiantoro, \& Triana Ahdiati \\ Department of Political Science, Faculty of Social and Political Science, Universitas Jenderal Soedirman \\ Address: Jalan Kampus 12, North Purwokerto, Banyumas, Central Java 53122 \\ E-mail: solahuddin.kusumanegara@gmail.com
}

\begin{abstract}
The local government of Purbalingga and society develops Owabong to increase their economic condition. The development has set as a model for other regions. This study aims to describe the policy evaluation of Owabong development as a leading tourist attraction in Purbalingga, Central Java. The study uses a qualitative method with a case-study approach equipped with quantitative data in the form of survey results - the data collected through the observation, in-depth interviews, and document studies. There are 15 informants taken purposively for the interviews, and 76 respondents were randomly selected for the survey sample. The research uses the interactive analysis technique from Miles \& Huberman and descriptive statistics analysis to analyze it. The result shows that a low Human Development Index (HDI) associated with a low economic level encourages the government to develop tourism in Purbalingga. The compilation of the particular regulation on Owabong becomes the basis for planning leading tourism development and its implementation compiled by the authorities $(87.72 \%)$. Based on the regional regulation, the local government, through the regional company of Owabong, succeeds in developing Owabong as a leading tourist attraction and has a positive impact on the local government itself as well as the surrounding communities. Throughout 2016, the regional company of Owabong has contributed to the original regional income of Purbalingga up to 6.684.178.335 IDR. The existence of Owabong has guaranteed business opportunities to the surrounding communities $(85 \%)$ and increased their income $(90 \%)$, the level of community support for the existence of Owabong is $100 \%$, the leaders have succeeded in establishing the cooperation of top and bottom line $(82.46 \%)$. The main factors of being successful are the existence of special regional regulation on leading tourist attractions managed by regional companies, apparatus compliance in carrying out the development as planned, the support from the communities around the tourism object, and leadership. So, the policy of developing tourism through regional regulation before a leading tourist attraction has successfully achieved the goals. In conclusion, the government has succeeded in using social capital as well as the power to reach the goals.
\end{abstract}

Keywords: Owabong; policy evaluation; apparatus compliance; community support; leadership

\begin{abstract}
Abstrak
Pemerintah Kabupaten Purbalingga bersama masyarakat mengembangkan Owabong untuk meningkatkan taraf ekonominya. Karena pengembangan tersebut dapat menjadi contoh bagi daerah lain, maka hasil dari penelitian bertujuan untuk mendeskripsikan evaluasi kebijakan pengembangan Owabong sebagai objek wisata unggulan di Kabupaten Purbalingga, Provinsi Jawa Tengah. Metode yang digunakan adalah metode kualitatif dengan pendekatan studi kasus yang dilengkapi dengan data kuantitatif berupa hasil survei. Data dikumpulkan melalui teknik observasi, wawancara mendalam, dan studi dokumen. Informan diambil secara purposif sebanyak 15 orang dan sampel untuk survei diambil secara random sebanyak 76 orang. Sementara analisis datanya menggunakan teknik analisis interaktif dari Miles dan Huberman dan analisis deskriptifstatistik. Hasil penelitian tersebut mengungkapkan bahwa Indeks Pembangunan Manusia yang rendah dan terkait dengan taraf ekonomi yang rendah mendorong pemerintah mengembangkan pariwisata di Kabupaten Purbalingga dan penyusunan Peraturan Daerah (Perda) khusus Owabong yang menjadi dasar perencanaan pengembangan pariwisata unggulan dan pelaksanaannya dipatuhi oleh aparat $(87,72 \%)$. Berdasarkan perda tersebut, Pemerintah Kabupaten melalui PD Owabong berhasil mengembangkan Owabong sebagai objek wisata unggulan dan memberikan dampak positif bagi pemerintah kabupaten dan masyarakat sekitar. Sepanjang Tahun 2016, PD Owabong memberikan sumbangan untuk PAD Kabupaten Purbalingga sebesar Rp 6.684.178.335. Di samping itu, keberadaan Owabong juga telah memberi jaminan kesempatan berusaha kepada masyarakat sekitar (85\%) dan meningkatkan pendapatan mereka (90\%), tingkat dukungan masyarakat terhadap keberadaan Owabong adalah sebesar 100\%, pemimpin berhasil menjalin kerja sama atasan-bawahan (82,46\%). Faktor keberhasilan yang utama adalah keberadaan peraturan daerah khusus wisata unggulan yang
\end{abstract}


dikelola oleh perusahaan daerah, kepatuhan aparatur dalam melaksanakan pengembangan sesuai dengan perencanaannya, dukungan masyarakat sekitar objek wisata, dan kepemimpinan. Dengan demikian kebijakan pengembangan pariwisata yang diatur dengan Perda khusus obyek wisata unggulan telah berhasil mencapai tujuannya. Pemerintah berhasil memanfaatkan modal sosial dan kekuasaannya untuk mencapai tujuan.

Kata kunci: Owabong; evaluasi kebijakan pariwisata; kepatuhan aparat; dukungan masyarakat; kepemimpinan

\section{Introduction}

In the past decades, tourism has enjoyed growing popularity, especially in developing countries that focused on their national economic development (Fiatiano 2007, Hampton \& Jeyachea 2015). Tourism has become a global trend as its popularity grows (Balaguer \& Cantavella-Jorda 2002, Khalil et al. 2007). Even though tourism development is different in each state, it holds the record of the fastest growing industry (Brida et al. 2008, Gunduz \& Hatemi 2005, Ozturk \& Acaravci 2009). Aside from the technology and information sector, tourism is one of the leading industrial forces in the century (Brida et al. 2014). Data from World Trade Organization (WTO) revealed that tourism is multiplying at $4.1 \%$ per year, absorbing 204 million workers, and has become the producer of $10.2 \%$ of the world's gross national product. In 2014, tourism growth reached 9.5 trillion USD (Lee \& Chang 2008, Susanto 2003). In various countries, the growth of tourism is used by the government to recover the national economy and strengthen the region through increased regional income (Nissan et al. 2011, Pedrana 2013).

In Indonesia, tourism development is nationally regulated in Regulation No. 10 of 2009 concerning tourism, whereas development on a regional scale regulated according to regional regulations. The constitution should be the base of regional policy. However, the era of decentralization provides flexibility to the region to develop and expand the tourism potential (Colfer \& Capistrano 2005, Lortanavanit 2009, Umardiono 2011, Yüksel et al. 2005). In Purbalingga Regency, tourism offered to the community as a regional comparative advantage based on natural potential. Three regional regulations underlie tourism, namely 1) Regional Regulation of Purbalingga No. 11 of 2015 concerning the Tourism Development Master Plan for Purbalingga Regency 2015-2025, 2) Regional Regulation of Purbalingga No. 17 of 2015 concerning Tourism Business Registration Signs provided by tourism business licenses, and 3) Regional Regulation of Purbalingga No.9 of 2011 concerning Regional Bojongsari Water Attraction Regional Company (Objek Wisata Air Bojowangi, hereafter referred to as Owabong), and Purbalingga Regency (the specific regulation concerning Owabong).

The government of Purbalingga is optimistic that tourism development is an alternative to encourage economic growth (Samimi et al. 2011, Sinclair 1998). Thus, the government has a strong commitment to developing tourism motivated by the following reasons 1) tourism has taken an essential role in economic development, indicated by the increase of public welfare, 2) tourism also has a significant contribution in regional economic development as instruments for increasing regional income, 3) the future of tourism is promising as it requires a targeted and professional measure to create a significant improvement, 4) tourism is one of the sub-sectors of the people's economic development, which has been determined as a development priority, 5) tourism could lead the development of other sectors that can affect the rate of economic growth in the region, and 6) tourism supports the growth of hospitalities industries such as hotels, restaurants and the informal sector, trade and handicraft industries, agriculture, and transportation.

Owabong is a leading tourist attraction and, to date, the largest in contributing to the Purbalingga regional revenue. The contribution of the Owabong Regional Company (RC) in 2015 amounted to 5.408.612.026 IDR. The amount rose in 2016 to 6.684.178.335 IDR. The amount of regional revenue from Owabong' is significant compared to other attractions in Purbalingga, as illustrated in Table 1. The success of Owabong's RC significant contribution to increasing regional government revenue motivated the study of Owabong management based on Regional Regulation No. 9 of 2011. The evaluation study conducted focused on aspects of compliance and experiences of Owabong management (Kusumanegara 2010). 
Table 1.

Government regional revenue managed

\begin{tabular}{|c|c|c|c|c|}
\hline \multirow{2}{*}{ Tourism Object } & \multicolumn{2}{|c|}{2015 (IDR) } & \multicolumn{2}{|c|}{2016 (IDR) Agustus } \\
\hline & Target & Revenue & Target & Revenue \\
\hline Lawa Cave & 450.000 .000 & 564.298 .000 & 500.000 .000 & 513.542 .000 \\
\hline MTL Jend, Sudirman & 22.500 .000 & 28.848 .000 & 28.000 .000 & 27.987 .500 \\
\hline Wana Wisata Serang & 1.500 .000 & 2.500 .000 & 2.500 .000 & 1.250 .000 \\
\hline Slamet Mountain & 14.000 .000 & 28.000 .000 & 50.000 .000 & 65.400 .000 \\
\hline Petilasan Ardi Lawet & 7.000 .000 & 7.140 .600 & 7.500 .000 & - \\
\hline Mahesa Jenar Stadium & 15.000 .000 & 20.265 .000 & 20.000 .000 & 16.900 .000 \\
\hline Buper Munjulluhur & 120.000 .000 & 112.489 .900 & 105.000 .000 & 74.260 .000 \\
\hline Goentoer Darjono Stadium & 120.000 .000 & 68.600 .000 & 80.000 .000 & 58.394 .000 \\
\hline & 750.000 .000 & 832.141 .500 & 793.000 .000 & 757.733 .500 \\
\hline
\end{tabular}

\section{Research Method}

In accordance with Ambrosie (2010), this study employs qualitative methods augmented with quantitative methods. The qualitative method uses a case study approach. There are 15 informants for the study, including Director Owabong RC, Board of Trustees, Bojongsari Village Head, Bojongsari Village Community Leader, Traders Association Chairperson, Head of Pokdarwis Mudal Sari Bojongsari Village, and Tourists. A case study is a type of research conducted intensively, deeply, and comprehensively (Yin 2006). Quantitative methods are employed to explain indicators of Owabong's development policy evaluation, such as the Regional Regulation No. 9 of 2011 through the survey. The survey targeted the following groups: management of the Owabong (regional-owned enterprises), the Bojongsari Village Government apparatus, community groups, the community around tourist attractions, and tourists. Samples taken from 76 informants used a random method. Data analyzed using the interactive analysis of Miles \& Huberman (1992) supplemented by descriptive-statistical analysis for surveys.

\section{Result and Discussions}

Purbalingga Regency is a developing region in Central Java Province. Until the current date, the government has highly focused on improving economic growth. According to the Human Development Index (HDI), Purbalingga Regency classified as the five less-developed districts compared to 36 districts in Central Java. In 2018, the government launched a program to increase the HDI from $67.5 \%$ in 2016 to $68.5 \%$ in 2018 . Data gathered by researchers revealed that the economic and HDI improvement was closely related; thus, they should be implemented in parallel circumstances. Improving the economy will encourage the development of education and health facilities, leading to better public service delivery. Given the background, the regional government is optimistic that the tourism sector should be developed more in a more sophisticated measure to support economic growth and improvement in the welfare of Purbalingga citizens. The method to boost tourism is a common strategy in developing countries. Studies on the development of natural tourism in underdeveloped regions on the coast of Mexico show how the government shows commitment to developing tourism at the national level using public funds. The development of tourism will encourage the development of other economic sectors and long-term effects in increasing economic growth (Faber \& Gaubert 2019, Ongan \& Demiroz 2005).

Purbalingga Regency is a low-lying area surrounded by the Slamet Mountains, the Dieng Plateau, and traversed by the Serayu River and Klawing River. The terrain is full of tourism potential and considered strategic for the development of nature tourism. The government should explore the potential of nature tourism to generate profit and increase regional revenue. Informants explained that the government's commitment in tourism development was motivated by following considerations 1) tourism has played an essential role in development which is positively related to the community economic development, 2) tourism development also has a significant contribution in regional 
economic improvement as an instrument for increment on regional, regional revenue, 3) tourism development of strategic tourism must be worked out in a directed and professional manner, 4) tourism is one of the economic development sub-sectors that has been determined as a prime mover for development of other sectors to affect regional economic growth, and 5) tourism supports the growth of hospitality sectors such as hotel, restaurant, trade and handicraft industries, agriculture in a broad sense, and transportation.

In implementing the strategy, the government took initiatives to explore the strategic tourism potential. The initiatives included: 1) developing tourism destinations with unique specialty, attraction, and safe access expected to increase community income and regional income without undermining the value of environmental sustainability, customs, culture, and religion, 2) maintaining effective tourism marketing strategy to increase the visit from domestic and international tourists, 3) building a competitive tourism strategy with high capability to drive the people's economy, business partnerships, and enforce the preservation of the natural and socio-cultural environment, and 4) building an organized tourism institution within government organizations, the private sector and the community, including improvement in human resources, regulations, service optimization, and operational mechanisms. The measure aims to encourage the realization of sustainable tourism development. Theoretically, the government formulates tourism policy to provide a foundation on the tourism development continuity to enhance economic growth. The sustainability of tourism development policies is also directed toward sustainable development, especially in the environmental sector. However, tourism policy, in general, is still unevenly focused on increasing economic growth (Dritsakis 2004, Guo et al. 2019, Ongan \& Demiroz 2005). Economic-based improvement for tourism policy is also adopted by the Purbalingga Regency to improve the economic level of the community and the region.

The policy formulated in the form of a regional regulation formulated and functioned as the primary regulation for tourism development. Regional Regulation No.11 of 2015 concerning the Tourism Development Master Plan for Purbalingga Regency 2015-2025, Regional Regulation No.17 of 2015 concerning Tourism Business Registration Certificate that regulates tourism business licensing, and Regional Regulation No. 9 of 2011 concerning Regional Bojogsari Water Attraction Company in Purbalingga Regency (the specific regulation that manages Owabong). Various emerging tourism objects managed by the district government, private parties, and the community under the Tourist Attractions and Attractions (ODTW). Owabong is one of the natural tourism-based ODTWs managed by the government; namely, it is in the form of a Regionally-Owned Enterprise or Badan Usaha Milik Desa (BUMDes). Owabong is currently the most developed tourism attraction in Purbalingga Regency.

Aside from the regulation of tourism, another essential element in tourism development is planningtourism development in the Purbalingga Regency as an integral part of regional development performed sustainably. The aim is to improve the regional community's abilities in utilizing science and technology by addressing the challenges of the development of global society. The comprehensive and integral development of tourism by utilizing the wealth of natural resources, culture, and geographical conditions will create a prosperous community life in Purbalingga. In addition, the development of tourism expected to encourage regional development, reduce disparities between regions, and encourage the utilization of each region's potential and capacity. In developed countries, regional tourism planning arranged according to national planning. The goal was to reduce economic disparities between regions. Both government and communities are involved in the planning process (Baidal 2004), which covers the issue of regional disparities in the development of tourism, as Purbalingga still categorized as an impoverished region. Planning refers to a national scale; however, there is still no planning formulated by the community that integrates with regional planning. Community planning is limited to the implementation of the rural tourism program.

Tourism development requires clear concepts and strategies. In Regulation No. 10 of 2009 concerning Tourism, Article 8 explains that tourism development is carried out based on the tourism development master plan, which consists of the national tourism development master plan, the provincial tourism development master plan, and the district or city (tourism development master plan). At the national 
level, tourism development regulated in Law No. 10 of 2009: Tourism, long-term development plan or medium-term development plan, and national tourism development master plan. At the provincial level, tourism destinations are regulated through regional tourism development master plan, district, or city destinations through Regency or city (regional tourism development master plan). In contrast, destinations at the regional level are regulated through a regional development master plan, while the tourist attraction issues are regulated through regional site plans and technical designs.

Implementation of Law No. 10 of 2009 on Tourism led to the formulation of Regional Regulation No.11 of 2015 concerning the Purbalingga Regency Regional Tourism Development Plan. The regional regulation emphasizes tourism development in Purbalingga Regency as an integral part of regional development, also like the implementation of the long-term development plan. The commitment shows that tourism development in Purbalingga Regency is an inseparable part of tourism development on a provincial and national level. Tourism is one of the leading sectors of industry in Purbalingga. The development should be conducted in a professional measure to enhance Purbalingga tourism's contribution as a reliable source of revenue in the future. Strengthening the tourism sector will help improve regional comparatives and competitive advantages for Purbalingga on regional and national tourism maps. Improving comparatives and competitive advantages in Purbalingga based on the following measure, 1) development and management tourism and Purbalingga has set the area as a reference for other areas in building the sector, such as Banyumas, Pekalongan, and Grobogan, 2) there is an expectation toward substantial cooperation between supporting part in tourism, such as hospitality, tourism agency, the culinary sector, handicraft makers, and 3) the natural and cultural potential that creates a tourism village in Purbalingga. They utilize natural potential to attract visitors and in improving village revenue.

Especially in increasing village revenue, Purbalingga Regency Government keeps developing tourism in the village area. One of the main strategies is to flourish potential tourist villages to boost the number of visitors. The government has applied several measures, 1) it has invested in human resources in the tourism sector, 2) conducted a comparative study to the more well-established tourist villages, and 3) then it has provided special fund assistance since 2015 to stimulate the growth of tourist villages. The amount of funds provided is 1 billion IDR, which increased to 1.8 billion IDR in 2016 with 15-20 tourist villages set as an example. Tourism development in Purbalingga Regency is unique because it is regulated by two regional regulations, namely Regional Regulation No. 11 of 2015 concerning the Regional Tourism Development Master Plan for Purbalingga Regency 2015-2025 (RIPP) and Regional Regulation No. 9 of 2011 concerning Regional Bojongsari Water Attraction Tourism Enterprises in Purbalingga Regency. The RIPP Regulation underlies the development of tourism objects under the auspices of the Department of Youth Sports and Tourism or Dinas Pemuda, Olahraga, dan Pariwisata (Dinporapar), including Goa Lawa, Jenderal Soedirman Monument, and Munjul Luhur Campsite. While Regional Regulation No. 9 of 2011 concerning Regional Bojongsari Water Attraction Regional Company, Purbalingga District, Owabong, underlies the development of Owabong. Regional regulation governing Owabong was implemented four years before the enactment of the Regional Regulation on RIPP.

Regional Regulation No. 11 of 2015 concerning the Regional Tourism Development Master Plan for Purbalingga Regency 2015-2025 (RIPP) was formulated based on the uniqueness, beauty, and value of diversity of natural, cultural, and human-made diversity in Purbalingga. The valuable asset will benefit the government and community through tourism businesses in Purbalingga. Based on these considerations, the objectives of Regional Regulation No. 11 of 2015 mentioned as follows 1) improve the quality and quantity of tourism destinations, 2) improve the regional economy, 3) employ marketing media effectively, efficiently and responsibly, 4) develop tourism institutions (networks) and professional tourism management, and 5) synergize the development of tourism destinations, tourism marketing, and the tourism industry.

Underlying its implementation, Regional Regulation No. 11 of 2015 adheres to the principle of tourism development sustainability. This regulation functions as the initial plan for all tourism development 
efforts in Purbalingga Regency. Therefore, the RIPP Regulation contains the substance policy in general. RIPP Regulation does not explicitly regulate the organization of various tourist objects in the Purbalingga Regency. According to the primary research source, the lack of specific rules caused the development of tourism objects under the auspices of the Department of Youth Sports and Tourism to proceed slowly. In 2015 and 2016, attractions under the auspices of the Department of Youth Sports and Tourism contributed less than 1 billion in original regional revenue. The situation was different from Owabong management, which professionally arranged through separate policies and different implementing actors four years before the RIPP Regulation formulated. However, according to the informants, the contents of the Owabong regional regulation did not contradict the RIPP Regulation as the umbrella. The contents and objectives of the regional regulation Owabong are in line with the principle of sustainability of tourism development as determined by the RIPP Regulation.

The operation of Owabong is based on a separate regulation, Regional Regulation No. 9 of 2011, and implemented by regional companies. In accordance with the contents of the regional regulation, in general, the regional regulation aims to provide business opportunities and benefits and improve the welfare of the community. To achieve this goal, the management of Owabong based on innovative, creative, and excellent service principles. In addition, the regional regulation stipulates the necessity to develop tourism objects, including 1) maintenance of a clean and comfortable environment, 2) providing security and safety for tourists, 3) developing marketing, 4) establishing and enhancing cooperation with travel agents and the community, 5) developing recreational facilities according to the needs of tourists and market demands, 6) compiling Owabong development plans, 7) carrying out supervision, and 8) implementing employee development.

Informants explained eight strategies that have become the base of Owabong's development and management, as follows. First, the aspect of maintaining cleanliness and the environment carried out leads to two objectives, namely: 1) providing a comfortable atmosphere for tourists so they will extend their visit to Owabong. The length of visit in Owabong will have more income impact because of the enormous possibility that different objects in the Owabong environment will get visits from tourists and 2) environmental preservation is a commitment from PD Owabong's managementoriented toward the aspect of sustainability in tourism development and increasing economic benefits, not limited to the Government of Purbalingga Regency, but also the community. Informants added that the most critical part of achieving the goals is by following the regulation and becoming a leadership criterion in Owabong. In this case, the survey data show that cleaning is done optimally (77.19\%). This situation is in line with the results of observations and in-depth interviews, which show that cleanliness efforts carried out before tourists arrive (morning) and after tourists leave the location (evening). The community stated that the effort to preserve Owabong location as clean and comfortable had been optimally performed ( $80 \%)$. Observations and interviews with the community revealed that both the inside and outside of the location regularly cleaned. Tourists consider that the Owabong neighborhood is clean enough with a high rate of $95 \%$.

Second, providing security and safety to visitors is an Owabong management priority. To date, there has never been a criminal case or severe injury inside the object location, although, in the outside area, there has been a case of theft helmets and motorcycles. To overcome this case, the management of Owabong works closely with the surrounding community and village government to provide better security at the parking location. They have planned to install CCTV cameras around the parking lot and on-site as a preventive measure. Owabong's management always emphasizes the importance of security during meetings and coordination. A survey regarding the provision of security showed that $77.19 \%$ of respondents thought security is sufficiently guaranteed. The surrounding community stated Owabong had guaranteed security $100 \%$, and $94.29 \%$ of tourists shared the same views as the community. Aside from security, the management also concerned about providing safety for tourists, and $90 \%$ of respondents perceived that management had provided the guarantee of safety. In comparison, $91.43 \%$ of tourists stated that the safety of tourists entirely guaranteed during their visit to Owabong. 
Third, management is putting much consideration into marketing development in every meeting; they have an online platform for marketing through web address https://owabong.co.id that collaborates with community blocks and travel agencies. Qualitative data show that travel agents are one of the essential channels in promoting tourism. The majority of the respondents $(77.19 \%)$, working together with the tourism agency, had been running effectively and had successfully increased tourists based on the results of the survey. For example, Perwira Tours offers tour packages, and Owabong is one of the tourist destinations. Promotion through travel agencies still leaves many spaces for further development. The management states that cooperation with travel agencies began in 2017 as well as the expansion of tourism support facilities such as hotel and restaurant entrepreneurs. Tourism promotion carried out in line with the intensification of recreational facilities and developments in the attraction site. Thus, it will increase the number of tourists and bring more benefits to the community. The management is optimistic that the improvement will be achieved by Owabong because the target needed to be compensated gradually increasing.

Fourth, cooperation with the tourism agency also developed with the community around the tourist attraction. The community has supported the development of Owabong and has benefited from the activities. According to the survey results, $85 \%$ of the people stated that Owabong had guaranteed business opportunities to the surrounding community, and $90 \%$ said they had increased their incomes, concluding that the relations between management and the community are wellestablished. The survey shows that $85.96 \%$ of informants experienced good cooperation between managers and the community. This figure is in line with good cooperation between managers and surrounding community groups (associations, village government, $R W, R T$ ). Around $89.47 \%$ of respondents thought that the management had cooperated well with the community groups. The positive cooperation between the management and community that positively contributed to public welfare has boosted community support in the development of Owabong, and $100 \%$ of respondents from the community stated they supported the development of Owabong.

Fifth, the development of recreational facilities is an essential requirement in interpreting tourism as a commodity. For this reason, a trend in market demands became the government's primary concern. Tourism market management not only clean demand ambiance, security, and comfort, but also variations in tourist facilities. Motivated by the needs of recreational facilities, Owabong has developed various tourist attractions. To date, the recreational facilities have expanded to include: Sagara Owabong wave pool, Olympic pool, surfboard, water boom, spilled bucket, flying fox, game pool, heretical pool, tsunami free beach, water party pool, pond fish therapy, hot tubs, 4D theater, rafting adventure, and aerospace facilities. Furthermore, Owabong provides a cottage to facilitate tourists staying over.

Sixth, Owabong management based on the principles of regional regulations. Objectives mentioned in the regional regulations are inseparable from the references used by the authorities in management at Owabong. The references are Regional Regulations No. 9 of 2011 (21.05\%), activity planning $(50.88 \%)$, leadership orders $(12.28 \%)$, and operational guidelines $(7.02 \%)$. Thus, legal and management rules have been implemented in the management of Owabong by employees. The data show that planning is an important aspect. Owabong's development activities have been based on this planning. As many as $36.84 \%$ stated that planning realized entirely, and $50.88 \%$ stated that most of it had been realized. In total, the figure for planning realization in the development of tourist objects is $87.72 \%$.

Seventh, according to the provisions of Regional Regulations No. 9 of 2011, the task of supervision is carried out by a Regulatory Body of Owabong RC board. In general, supervision duties have significantly been carried out by the Supervisory Agency, as was stated by the majority of respondents (78.95\%). The supervision is related to the development of programs and work plans conducted by the directors (Articles 36 and 38). Based on Regional Regulation No. 9 of 2011 the Regulatory Body is included in the Owabong management structure. In accordance with the results of interviews with resource persons, the supervisory agency is Owabong's internal organization is more oriented to the supervision of directors and policy aspects (planning and programs). But, in the field, the 
supervision aspect also contributes to the development of attractions. The majority of respondents (71.93\%) consider that supervision contributes as collateral for the development of attractions. A weak supervision will cause bad development of tourism objects. Thus strengthening the supervision is highly required as one of the determinants of the development of Owabong and other tourist objects in the future.

Eighth, Owabong employees' training is indirectly managed by the district government and directly carried out by the Owabong leadership. In the coaching of Owabong employees, informants revealed that meetings are an essential medium for establishing good cooperation between leaders and subordinates. In meetings, leaders stress the importance of developing Owabong by describing the planning and monitoring of its implementation and also explain the various problems that have arisen and searched for solutions by having the discussion and creative development. In addition, the leadership stressed officers' discipline in the development of Owabong. The survey shows that $82.46 \%$ of respondents believed that coaching employees improve cooperation between leaders and subordinates. In addition, good working relations between the leaders were caused by the direction of the leaders in accordance with the policies and programs they carried (84.21\%), while the cooperation between subordinates still needed to be increased (68.42\% of total respondents). Data show the low number of subordinates members are motivated by social jealousy in the office.

Furthermore, employee training has also improved the discipline of the apparatus in carrying out their duties. According to informants, the current discipline of the apparatus has improved significantly compared to the situation in the past (the beginning of Owabong's development). Along with the increase in Owabong revenue, the economic welfare of the officers has also been raised. The qualitative data supported by the results of a survey show that $73.16 \%$ of respondents stated that employees had been disciplined.

Table 2.

Survey result in Owabong Management (in percentage)

\begin{tabular}{|c|c|c|c|c|c|c|c|c|c|}
\hline \multirow{2}{*}{ Aspect } & \multicolumn{3}{|c|}{ Officers } & \multicolumn{3}{|c|}{ Community } & \multicolumn{3}{|c|}{ Tourists } \\
\hline & SS $^{\mathbf{a}}$ & $\mathbf{S}^{\mathbf{b}}$ & $\mathrm{TS}^{\mathrm{c}}$ & $\mathbf{S S}^{\mathbf{a}}$ & $\mathbf{S}^{\mathbf{b}}$ & TS $^{c}$ & $\mathbf{S S}^{\mathbf{a}}$ & $\mathbf{S}^{\mathbf{b}}$ & TS $^{\mathrm{c}}$ \\
\hline $\begin{array}{l}\text { Cleanliness and environment } \\
\text { maintenance }\end{array}$ & 77.19 & 14.04 & 8.77 & 80 & 20 & 0 & 95 & 5 & 0 \\
\hline Guarantee on security & 77.19 & 15.79 & 7.02 & 100 & 0 & 0 & 94.29 & 5.71 & 0 \\
\hline Guarantee on safety & 82.46 & 10.53 & 7.01 & 90 & 10 & 0 & 91.44 & 5.71 & 2.85 \\
\hline Cooperation with tourism agency & 77.19 & 14.04 & 8.77 & $\mathrm{~N} / \mathrm{a}$ & $\mathrm{N} / \mathrm{a}$ & $\mathrm{N} / \mathrm{a}$ & $\mathrm{N} / \mathrm{a}$ & $\mathrm{N} / \mathrm{a}$ & $\mathrm{N} / \mathrm{a}$ \\
\hline $\begin{array}{l}\text { Guarantee on business opportunity } \\
\text { of community }\end{array}$ & 82.46 & 7.02 & 10.52 & 85 & 10.51 & 4.49 & $\mathrm{~N} / \mathrm{a}$ & $\mathrm{N} / \mathrm{a}$ & $\mathrm{N} / \mathrm{a}$ \\
\hline Community revenue increasement & 82.46 & 8.78 & 8.76 & 90 & 8.77 & 1.23 & $\mathrm{~N} / \mathrm{a}$ & $\mathrm{N} / \mathrm{a}$ & $\mathrm{N} / \mathrm{a}$ \\
\hline $\begin{array}{l}\text { Management good cooperation } \\
\text { with the community }\end{array}$ & 85.96 & 7.02 & 7.02 & 90 & 8.77 & 1.23 & $\mathrm{~N} / \mathrm{a}$ & $\mathrm{N} / \mathrm{a}$ & $\mathrm{N} / \mathrm{a}$ \\
\hline $\begin{array}{l}\text { Management good cooperation } \\
\text { with groups in community }\end{array}$ & 89.47 & 3.51 & 7.02 & 80 & 20 & 0 & $\mathrm{~N} / \mathrm{a}$ & $\mathrm{N} / \mathrm{a}$ & $\mathrm{N} / \mathrm{a}$ \\
\hline $\begin{array}{l}\text { Community support toward } \\
\text { Owabong development }\end{array}$ & $\mathrm{N} / \mathrm{a}$ & $\mathrm{N} / \mathrm{a}$ & $\mathrm{N} / \mathrm{a}$ & 100 & 0 & 0 & $\mathrm{~N} / \mathrm{a}$ & $\mathrm{N} / \mathrm{a}$ & $\mathrm{N} / \mathrm{a}$ \\
\hline Recreational facilities development & 61.40 & 31.58 & 7.02 & 85 & 15 & 0 & 80 & 20 & 0 \\
\hline Planning and implementation & 87.72 & 3.51 & 8.77 & $\mathrm{~N} / \mathrm{a}$ & $\mathrm{N} / \mathrm{a}$ & $\mathrm{N} / \mathrm{a}$ & $\mathrm{N} / \mathrm{a}$ & $\mathrm{N} / \mathrm{a}$ & $\mathrm{N} / \mathrm{a}$ \\
\hline Surveillance effectivity & 78.95 & 14.04 & 7.01 & 70 & 30 & 0 & $\mathrm{~N} / \mathrm{a}$ & $\mathrm{N} / \mathrm{a}$ & $\mathrm{N} / \mathrm{a}$ \\
\hline Surveillance intensity & 78.95 & 14.04 & 7.01 & 60 & 35 & 5 & $\mathrm{~N} / \mathrm{a}$ & $\mathrm{N} / \mathrm{a}$ & $\mathrm{N} / \mathrm{a}$ \\
\hline $\begin{array}{l}\text { Contribution of surveillance } \\
\text { towards=Owabong Development }\end{array}$ & 71.93 & 21.05 & 7.02 & 70 & 15 & 15 & $\mathrm{~N} / \mathrm{a}$ & $\mathrm{N} / \mathrm{a}$ & $\mathrm{N} / \mathrm{a}$ \\
\hline Leaders-officers cooperation & 82.46 & 10.53 & 7.01 & $\mathrm{~N} / \mathrm{a}$ & $\mathrm{N} / \mathrm{a}$ & $\mathrm{N} / \mathrm{a}$ & $\mathrm{N} / \mathrm{a}$ & $\mathrm{N} / \mathrm{a}$ & $\mathrm{N} / \mathrm{a}$ \\
\hline $\begin{array}{l}\text { Leaders direction matches } \\
\text { program implementation }\end{array}$ & 84.21 & 7.02 & 8.77 & $\mathrm{~N} / \mathrm{a}$ & $\mathrm{N} / \mathrm{a}$ & $\mathrm{N} / \mathrm{a}$ & $\mathrm{N} / \mathrm{a}$ & $\mathrm{N} / \mathrm{a}$ & $\mathrm{N} / \mathrm{a}$ \\
\hline
\end{tabular}


Based on the analysis, we conclude that drivers of the development of Owabong are listed as follows: the enactment of regional regulations for the development of Owabong, officers' compliance in developing the objects, supporting communities around attractions, and ethical leadership of Owabong. In this case, Owabong RC is the main actor that has successfully managed power and social capital to achieve the goal. A study conducted by Singgalen (2016) also supports this view, which states that capital and social are two essential aspects of formulating and implementing tourism policy. In this case, power refers to government authority during the formulation and implementation of the Owabong development policy — social capital defined as support from the community. Social supports are closely related to the policy regarding poverty alleviation, and Owabong regarded as one way out to reach a better economic condition.

\section{Conclusion}

Based on the data and the results of the discussion, it can be concluded that the regional government perceives the tourism sector as a solution to improve the economic level of the community and boost the HDI of Purbalingga Regency classified as low in Central Java. Owabong is one of the government strategies in tackling the issue. In its development, Owabong has become a leading tourist attraction in Purbalingga Regency and contributes to the most substantial local original revenue from the tourism sector. Throughout 2016, Owabong RC contributed to the Purbalingga Regency revenue amounting to 6.684.178.335 IDR. Owabong's success was also demonstrated by its expansion toward other business opportunities for the surrounding community and increasing community income. Therefore, community support for the existence and sustainability of Owabong is enormous.

The development of Owabong is in accordance with the policies of the Purbalingga Regency Government as regulated in Regional Regulation No. 9 of 2011 and implemented by regional companies. The regional regulation formulated explicitly to encourage Owabong as a leading tourist attraction. Regional regulations stipulate eight aspects as the basis for implementing the development: 1) maintenance of cleanliness of the environment, 2) provide security and safety for tourists, 3) develop marketing, 4) establish and enhance cooperation with travel agencies and the community, 5) develop recreational facilities according to the needs of tourists and market demands, 6) formulating Owabong development plans, 7) performing supervision, and 8) implementing employee coaching. These eight aspects have been successfully implemented with relative consistency by regional companies so that the purpose of the regional regulation to provide opportunities for community and improve community welfare can be achieved. Overall, it can be interpreted that the strong elements driving the success of the development of Owabong are the existence of significant regional regulations for the development of Owabong, apparatus compliance in carrying out development, community support around attractions, and proper leadership.

\section{References}

Ambrosie LM (2010) Tourism policy research: Avenues for the future. International Journal of Tourism Policy 3 (1):33-50. http://doi.org/10.11575/PRISM/34091.

Baidal JAI (2004) Regional tourism planning in Spain: Evolution and Perspective. Annals of Tourism Research 31 (2):313-333. https://doi.org/10.1016/j.annals.2003.12.001.

Balaguer J \& Cantavella-Jorda M (2002) Tourism as a long-run economic growth. Applied Economics 34 (7):877-884. https://doi.org/10.1080/00036840110058923.

Brida JG, Pereyra JS \& Devesa MJS (2008) Evaluating the contribution of tourism to economic growth. An International Journal of Tourism and Hospitality Research 19 (2):351-357. https://doi.org/10.1080/13032917.2008.9687079.

Brida JG, Cortez-Jimenez I \& Pulina M (2014) Has the tourism-led growth hypothesis been validated? A literature review. Current Issues in Tourism 19 (5):1-37. https://doi.org/10.1080/136835 00.2013 .868414 .

Department of Youth Sports and Tourism (2016) Laporan Pengembangan Pariwisata Kabupaten Purbalingga. Unpublished. 
Lee CC \& Chang CP (2008) Tourism development and economic growth: A closer look at panels. Tourism Management 29 (1):180-192. https://doi.org/10.1016/j.tourman.2007.02.013.

Colfer CJP \& Capistrano D (2005) The Politics of Decentralization: Forest, Power and People. London: Earthscan.

Dritsakis N (2004) Tourism as a long-run economic growth factor: An empirical investigation for Greece using Causality Analysis. Tourism Economics 10 (3):305-316. https://doi.org/10.53 67/0000000041895094.

Faber B \& Gaubert C (2019) Tourism and economic development: evidence from Mexico's coastline. American Economic Review 109 (6):2245-2293. https://doi.org/10.1257/aer.20161434.

Fiatiano E (2007) Tata cara mengemas produk pariwisata pada daerah tujuan wisata. Masyarakat, Kebudayaan dan Politik 20 (3):165-174.

Gunduz L \& Hatemi-J A (2005) Is the tourism-led growth hypothesis valid for Turkey? Applied Economics Letters 12 (8):499-504. https://doi.org/10.1080/13504850500109865.

Guo Y, Jiang J, \& Li S (2019) A sustainable tourism policy research review. Sustainability 11 (11):116. https://doi.org/10.3390/su11113187.

Hampton MP \& Jeyachea J (2015) Power, ownership and tourism in small islands: Evidence from Indonesia. World Development 70:481-495.https://doi.org/10.1016/j.worlddev.2014.12.007.

Khalil S, Kakar MK \& Waliullah (2007) Role of tourism in economic growth: Empirical evidence from Pakistan economy. The Pakistan Development Review 46 (4):985-995.

Kusumanegara S (2010) Model dan Aktor dalam Proses Kebijakan Publik. Yogyakarta: Gavamedia.

Lortanavanit D (2009) Decentralization, empowerment and tourism development: Pai Town in Mae Hong Son, Thailand. South Asian Studies 47 (2):150-179.

Miles MB \& Huberman MA (1992) Analisis Data Kualitatif: Buku tentang Metode-Metode Baru. Jakarta: UI Press.

Nissan E, Galindo M \& Mendez MT (2011) Relationship between tourism and economic growth. The Service Industries Journal 31 (10):1567-1572. https://doi.org/10.1080/02642069.2010. 485636.

Ongan S \& Demiroz DM (2005) The contribution of tourism to the long-run Turkish economic growth. Ekonomicky Casopis 53 (9):880-894.

Ozturk I \& Acaravci A (2009) On the causality between tourism growth and economic growth: empirical evidence from Turkey. Transylvanian Review of Administrative Sciences 25 (E): 73-81.

Pedrana M (2013) Local economic development policies and tourism an approach to sustainability and culture. Regional Science Inquiry Journal 5 (1):91-99.

Samimi AJ, Sadeghi s \& Sadeghi S (2011) Tourism and economic growth in developing countries: P-VAR-approach. Middle-East Journal of Scientific Research 10 (1):28-32.

Sinclair MT (1998) Tourism and economic development: A survey. The Journal of Development Studies 34 (5):1-51. https://doi.org/10.1080/00220389808422535.

Singgalen, YA (2016) Persepsi, Modal Sosial, dan Kekuasaan Aktor dalam Perumusan Kebijakan Pariwisata. Pax Humara 3 (2):081-104.

Susanto H (2003) Otonomi Daerah dan Kompetensi Lokal: Pikiran serta Konsepsi Syaukani HR. Jakarta: Millenium Publisher.

Umardiono A (2011) Pengembangan obyek wisata Taman Nasional Laut Kepulauan Karimun Jawa. Masyarakat, Kebudayaan dan Politik 24 (3):192-201.

Yin RK (2006) Studi Kasus: Desain dan Metode. Jakarta: Raja Grafindo Persada.

Yüksel F, Bramwell B \& Yüksel A (2005) Centralized and decentralized Tourism governance in Turkey. Annals of Tourism Research 32 (4):859-886. https://doi.org/10.1016/j.annals. 2004.09.006. 